\title{
PARTICULARITIES CONCERNING THE BENEFICIARIES OF AUDIT SERVICES PROVIDED BY THE BIG 4 COMPANIES: EVIDENCE FROM ROMANIA
}

\author{
Sorin Romulus Berinde ${ }^{1}$ \\ Adrian Groşanu ${ }^{2}$
}

\begin{abstract}
This study aims to explore some particularities concerning the Romanian audited entities which are oriented mainly towards contracting audit services from the largest companies providing auditing services (Big 4 companies). The assessment criteria taken into consideration for the differentiation of the beneficiaries of the audit services, at Romanian level are related to competitiveness, to the structure of share capital and to the nature of the audited entities' management. There was taken into consideration the impact differentiation of each indicator, by coefficients of importance. If at international level, previous results show a supremacy for the Big 4 audit services providers, not the same situation confirms at Romanian level. The results show that only $18 \%$ of the sampled audited entities benefit from audit services provided by the Big 4, irrespective of their level of competitiveness, the structure of share capital or the structure of management.
\end{abstract}

Key words: audited entities; audit services provider; structure of share capital; structure of management; statistical methods

JEL Codes: M42, M41, M48

\section{Introduction}

A system of corporate governance involves continually finding those management strategies which maintain the entity's competitiveness (increasing the efficiency, the adaptability to market conditions and also its market value). In order to achieve this goal, this study aims to analyze the extent to which, for the audited entities, the structure of share capital (foreign or local participation), respectively the type of management (foreign or local management) are able to condition a certain level of competitiveness. This can be highlighted by the indicators of financial statements that refer to both the financial position and financial performance of the entities. On the other hand, there might be a tendency of the beneficiaries of audit services to resort to this kind of services provided by audit companies from the Big 4. In this regard, the options can be justified by a certain structure type of the share capital, by a certain type of management or by a certain level of competitiveness within economic entities.

Starting from the previous theoretical and empirical literature that support the assumption that there is a certain supremacy of Big 4 audit services providers, because they confer a greater credibility, which is very important for the audited entities strongly focused on performance developmentor for the family-held entities, this paper intends to develop an empirical analysis that could revealed any potential links between a certain structure type of the share capital, a certain type of management and their contribution to a certain level of competitiveness within economic entities, audited by Big 4 Companies.

The remainder of the paper is organized as follows. Section 2 briefly discusses the main results of the previous studies, trying to provide an adequate theoretical background for the purpose

\footnotetext{
${ }^{1}$ Babeş-Bolyai University, Cluj-Napoca, Romania, e-mail: sorin.berinde@tbs.ubbcluj.ro.

${ }^{2}$ Babeş-Bolyai University, Cluj-Napoca, Romania, e-mail: adrian.grosanu@econ.ubbcluj.ro.
} 
of this paper, Section 3 discusses the research design and methodology and develops the study's hypothesis, Section 4 reports the study's findings and finally Section 5 summarises the results and draws the conclusions.

\section{Literature review}

The specialized literature displays a tendency towards quantifying or building certain correlations between different particularities of the beneficiaries of audit services and the typology of such services' providers or particularities of the provided audited services. The studies published in this regard present these aspects from both a quantitative and qualitative perspective. Some studies approach the purpose of the audit activity within audited entities where the ownership structure is less diversified: the entities where ownership consists of members of the same family (Niskanen and Karjalainen, 2010). The study results reveal a tendency of the family-held entities towards contracting audit services for their financial statements rather as a formal action, in order to confirm credibility, placing less emphasis on audit quality. The results of this study indicate that family-held or -controlled firms are less likely to use Big 4 auditors than nonfamily firms and that an increase in family ownership decreases the likelihood of a Big 4 audit. Some studies confirm that large audit entities, from the Big 4 category, have the tendency to require audit services from performant companies (Basioudis \& Francis, 2007; Ireland \& Lennox, 2002) or companies from a certain field of activity (DeFond, Francis and Wong, 2000; Craswell, Francis and Taylor, 1995). These types of research indicate that the premium earned by large audit firms is more than twice as large when selectivity effects are taken into account (53.4\% compared to $19.2 \%$ ).

Asking if Big 4 auditors and Second-tier firms (the fifth and sixth largest audit firms: Grant Thornton and BDO Seidman) provide audits of similar quality, Boone et al. (2010) develops a study where the audit quality for Big 4 and Second-tier auditors was examined for a sample of US firms during 2003-2006. By using for measuring the audit quality proxies such as auditor's propensity to issue a going concern audit report for distressed clients; abnormal accruals as an observable proxy; and the client- and year-specific ex ante equity risk premium as a proxy for audit quality from the investors' perspective, the results of Boone et al. (2010) suggest that financial reporting quality is almost similar for entities audited by Big 4 and Second tier audit firms. Also, from the investor perspective, this study stressed the idea that investors are more likely to perceive accounting information quality to be higher for the entities audited by Big 4 than for entities audited by Second Tier audit firms. However any information provided by auditors must be based on the results of work performed by other professional accountants, including managerial accounting (Topor et al., 2011).

The Big 4 auditors take into consideration a very complex set of variables when establishing the level of audit fees and their structure (Caneghem, 2010). The hypothesis of a correlation between a certain type of management and the manner of planning and establishing the counterperformance of audit services is studied through certain qualitative aspects processed using a regression model (Bedard \& Johnstone, 2004). The study results revealed a relatively low intensity of the variables, which means that the professionalism of audit services is not influenced by the nature and structure of management. In order to protect the reputation, to reduce legal liability and to promote the shareholders' interests, a more independent, experienced and active management has high expectations regarding the quality of audit services, even if this implies higher costs (Carcello et all, 2002; Gotti et all, 2012). We frequently encounter studies which confirm and measure the intensity of the connection between the changes in fees for audit services and the change of these services' provider by the management of the audited entity (Simon and Francis, 1988; DeFond, 1992; Butterworth and Houghton, 1995; Gregory and Collier, 1996; Frankel, Johnson and Nelson, 2002), between the level of fees for audit services and the capital market's reaction to the publication of financial statements (Higgs and Skantz, 2006), between audit fees and the size of audit service providers (Francis, 1984; Palmrose, 1986; Thornton and Moore, 1993; Whisenant et 
all, 2003), between the size of audited entities and audit fees (Chan, Ezzamel and Gwilliam, 1993; Chung and Lindsay, 1988) and between the size of the financial audit providers and the beneficiaries of audit services at the same time (Ferguson and Stokes, 2002).

There are, also, authors who mention that the fact that large companies conclude contracts with large audit companies is not necessarily related to their prestige, the explanation being also the fact that a small auditor lacks the required workforce and time to audit a large beneficiary (Cameran, 2005). Some specialists argue that orienting beneficiaries towards auditors from the Big Six category is justified by the desire to confer credibility to an aggressive performance development (Francis et al., 1999). There are opinions which endorse the fact that the first six auditors at international level (Big 6) occupy these positions due to their cumulate implications worldwide (Weets and Jegers, 1997). According to these studies, at country level, audit services are focused less in favor of large auditors and more in favor of small auditors. The financial aspect of audit services is significant enough to create a mathematical model for determining the audit fees based on the following variables: the size of the audited entity (assessed on the basis of turnover and asset value), the size of the auditor (assessments regarding the perspectives of Big Eight auditors in this equation), whether or not there was a recent change of the auditor (Pong and Whittington, 1994).

The effects of management's structure on auditors' fees are also studied from the perspective of investors' involvement in the management of the audited entity. This is indirectly associated with the size of audit effort (Boța-Avram, 2012; Boța-Avram and Răchişan, 2013) and, implicitly, with the audit fees (Dickins \& Higgs, 2005). Thus, a 1\% increase of the investors' involvement in the management team can lead to a decrease of $1.4 \%$ of the audit fees. The issue regading the effect of the opinion expressed by the financial auditor within the audit report concerning share quotation on the stock market and the investment decision are also of large interest. The results of these studies are different. The unqualified opinion, the qualified opinion and the conditions of use of the opinion reports have not a clear and statistically significant effect on stock prices (Firth, 1978). The explanation may be the fact that the audit reports have a limited information content for the investors and it does not influence their opinion in the decision-making process. This may be due to the lack of understanding of the content, of the importance and value of this kind of reports. Other studies mention a decrease of share quotation after comunicating the qualified opinion expressed in the audit report (Dodd et all, 1984; Dopuch, Holthausen and Leftwich, 1986).

Therefore, after analyzing the specialized literature, one may notice that:

- the beneficiaries of audit services resort to the large entities which provide audit services because they confer a greater credibility. This aspect is crucial especially for the audited entities with a very good performance development or for the family-held entities;

- a management with a high degree of professionalism will mainly prefer audit services of high quality regardless of their cost;

- the studies regarding the impact of the auditor's qualified opinion on share quotation have different views on the evolution of share price after publishing the financial statements in question;

- although at international level the Big 4 auditors are prevailing, nationally there are situations in which the balance tips in the smaller auditors' favor;

- there is a inverse relationship between investors' involvement in the audited entities' management and the size of audit services fees.

\section{Research design and methodology}

Given the fact that the above mentined notions present high interest for analysis at international level, the objective of our study is to verify the following hypotheses regarding audited entities at national level in order to draw some conclusions at Romanian level: 
H1: Is there a condition between a certain structure of the share capital and of the management, on one side, and the audited entities' competitiveness, on the other side?

H2: Do the audited entities which are more competitive at national level manifest a tendency to request the audit services provided by entities from the Big 4 category?

H3: Is there a preference for Big 4 auditors also amongst Romanian audited entities?

The research methodology relies on a stratified sampling. This methodology is used by other researchers in the financial accounting field (Răchişan and Bonaci, 2007). This type of sampling has been customed fost the present study and it consists in obtaining certain references at regional level (North-West Region) which could allow us to extrapolate conclusions at national level concerning audited entities. This assumption is justified if we refer to the information published by the National Trade Register Office according to which the economic activity of North-West Region, in terms of frequency of registrations, mentions and deregistrations of economic entities carried out in the last 12 years is with $85.29 \%$ above the national average. Therefore, taking into consideration a particularly active economic activity, which complies perfectly at national level in what concerns the frequency of registrations, mentions and deregistrations, we can consider as relevant, at national level, the conclusions drawn from the present study, regarding the competitiveness of the entities which during 2005-2011 have been subjected to the financial audit. From a total number of 304 audited entities, 127 entities have been eliminated from the study as, for various reasons, they have not published their financial statements for the last 4 financial years. We opted to exclude these entities because we considered that it confers superior relevance to take into account for all audited entities the data published for the last 4 financial years in comparison with diminishing the number of financial years from the desire to include in the study a higher number of audited entities. In oder to achieve the objective of verifying the study's hypotheses we identified 4 categories of audited entities within North-West Region of Romania between 2005-2011:

- audited entities with foreign participation to the capital and foreign management $\left(C_{1}\right)$;

- audited entities without foreign participation to the capital and with foreign management $\left(C_{5} ;\right.$

- audited entities with foreign participation to share capital and without foreign management $\left(C_{i}\right)$;

- audited entities without foreign participation to share capital and without foreign management $\left(C_{49}\right.$.

For each category of entity audited between 2005-2012 was calculated a total of 9 indicators (criteria) considered relevant for asssessing competitiveness. These indicators are calculated starting from the accounting information related to the financial position and performance which have been published in the financial statements for the period 2008-2011. In order to ensure the relevance and credibility of the study's results, for each criterion (financial indicator) associated to the 4 categories of audited entities it was determined an average level in two stages: during the first stage an average was determined for each financial year from the 4 categories of audited entities, and the values obtained for each financial year have been subsequently aggregated as a single value, representative for all 4 financial years by calculating a simple arithmetic mean for the values of the financial years between 2008-2011. In order to establish a competitive ranking for these 4 categories of audited entities, we considered 4 types of competitiveness analysis methods well known in the specialized literature (Achim, 2009): the synthetic indicator method, the comparison matrix method, the distance method and the final scores method. Practically, the implementation of these methods has been achieved in two ways: the performance criteria are considered equally important, respectively they are differentiated by importance coefficients. The values of these selection coefficients was established on the authors' professional judgment, according to the individual relevance of each criterion for the audited companies' competitiveness so that by summing them all to get the value 1 . By including in the study a relatively high number of criteria for determining the competitiveness of these 4 categories of audited entities we are able to reduce a possible margin of error in establishing the coefficients of economic importance attributed by the authors for each criterion. 


\section{The criteria and coefficients of importance used in order to achieve competitiveness ranking}

\begin{tabular}{|c|c|c|c|c|c|c|c|c|}
\hline \multirow[t]{2}{*}{$\begin{array}{l}\text { No. } \\
\text { crt. }\end{array}$} & \multicolumn{3}{|c|}{$\begin{array}{l}\text { Criteria for determining the audited entity's } \\
\text { competitiveness }\end{array}$} & \multirow{2}{*}{$\begin{array}{c}\text { Coefficient } \\
\text { (percentage) } \\
\text { of economic } \\
\text { importance }\end{array}$} & \multicolumn{4}{|c|}{$\begin{array}{l}\text { Average value for each } \\
\text { category of audited entity } \\
\text { during 2008-2011 }\end{array}$} \\
\hline & Name & Type & Symbol & & $c_{3}$ & $c_{3}^{c}$ & $c_{3}$ & $c_{4}$ \\
\hline 1 & $\begin{array}{l}\text { Rate of Financial } \\
\text { Authonomy }\end{array}$ & Direct & $R_{p i}$ & 0.12 & $52.0 \%$ & $58.0 \%$ & $58.3 \%$ & $65.3 \%$ \\
\hline 2 & Debt Ratio & Indirect & $D_{2}$ & 0.11 & $48.0 \%$ & $41.0 \%$ & $41.8 \%$ & $34.8 \%$ \\
\hline 3 & Debt to Equity Ratio & Indirect & $D_{p g}$ & 0.11 & $227.5 \%$ & $829.0 \%$ & $227.8 \%$ & $239.3 \%$ \\
\hline 4 & Rotation Speed of Equity & Direct & $R_{s z}$ & 0.10 & 5.8 & 4.5 & 6.0 & 1.5 \\
\hline 5 & $\begin{array}{l}\text { Rotation Speed of Total } \\
\text { Assets }\end{array}$ & Direct & $K_{i d}$ & 0.10 & 0.5 & 0.9 & 0.8 & 0.5 \\
\hline 6 & $\begin{array}{l}\text { Rotation Speed of Total } \\
\text { Debts }\end{array}$ & Direct & $K_{r s}$ & 0.10 & 0.6 & 2.4 & 1.3 & 0.9 \\
\hline 7 & Net Profit Margin & Direct & $N_{f x x}$ & 0.12 & $2.4 \%$ & $3.8 \%$ & $1.5 \%$ & $0.8 \%$ \\
\hline 8 & Return on Common Equity & Direct & $R_{c z}$ & 0.12 & $2.9 \%$ & $5.5 \%$ & $5.2 \%$ & $0.7 \%$ \\
\hline 9 & Return on Total Assets & Direct & $R_{i \bar{i}}$ & 0.12 & $0.7 \%$ & $3.6 \%$ & $1.9 \%$ & $0.2 \%$ \\
\hline
\end{tabular}

Source: Statistical processing performed by the authors

The first method of competitiveness analysis approached by the specialized literature used in this study, the synthetic indicator method, allows the ranking of the 4 categories of audited entities between 2005-2012, starting from the data published in the financial statements during 2008-2011, by calculating a weighted geometric mean of the performance criteria, as it follows:

$$
\begin{aligned}
& \text { Where, } \\
& \text { Isg(k) - the global synthetic indicator of the category of audited } \\
& \text { entities k; } \\
& I s g(k)=\sqrt[n]{\frac{\prod_{i=1}^{T_{1}} I l(k)}{\prod_{j=1}^{p} I j(k)}} \\
& I(k) \text { - the index of the direct performance "i" of the category of } \\
& \text { audited entities k; } \\
& l j(k) \text { - the index of the indirect performance criterion , j” of the } \\
& \text { company k; } \\
& m \text { - the number of direct performance criteria; } \\
& p \text { - the number of indirect performance criteria; }
\end{aligned}
$$

This method of calculation does not take into account the relevance of each criterion for determining competitiveness (statistical version). If taking into account this detail (economical version), the synthetic indicator method is applied as it follows:

$$
\begin{aligned}
& \text { Where, } \\
& I s c(k)=\sum_{=1}^{m} I i(k) x p i-\sum_{j=1}^{p} I j(k) x p j \text { "i"; } \\
& p i \text { - coefficient given to the direct performance criterion } \\
& p j-\text { coefficient given to the indirect performance } \\
& \text { criterion " } \mathrm{j} \text { ". }
\end{aligned}
$$

The highest value shall determine the most competitive category from the 4 categories of audited entities. The second method used for ranking the 4 categories of audited entities is the matrix comparison method and it involves using a matrix in which the lines "i" are the nine performance criteria, and the columns " $\mathrm{j}$ " are occupied by the categories of audited entities ranked 
according to the optimal value of these criteria. For each place in the hierarchy $(1 \mathrm{j})$ there will be etablished a score, in a descending manner, as it follows:

$$
l j \in\left\{\frac{1}{2^{2}}, \frac{1}{2^{2}}, \cdots, \frac{1}{2^{4}}\right\}, \mathrm{j}=\overline{1,4}
$$

Therefore, the matrix comparison method used to determine the competitiveness of the 4 categories of audited entities will apply as it follows:

$$
M c(k)=\sum_{i=1}^{m} l j x\left[\sum_{i=1}^{n} n i j(k) x p i\right] \begin{aligned}
& \text { Where, } \\
& M c(k)-\text { the indicator obtained from processing the data in } \\
& \text { matrix form for the category of audited entities "k"; } \\
& p i-\text { the importance coefficient given to the performance } \\
& \text { criterion "i". }
\end{aligned}
$$

The third method of competitiveness analysis used (the distance method) involves measuring the distance for each category of audited entites, for each performance criterion, until reaching the value considered optimal for a certain criterion. From the perspective of this study, for direct criteria, the optimal value will be considered the greatest, and for indirect criteria, the optimal value will be the lowest recorded. The category of audited entities with the lowest value of this indicator can be considered the most competitive. According to the application versions (statistical - without taking into consideration the importance coefficients or economical - with taking into consideration the performance coefficients for determining competitiveness), the calculation of distances is presented as it follows:

$$
\begin{aligned}
& \text { Where, } \\
& D e(k) \text { - the distance between each category of audited entities } \\
& \text { " } k \text { " and the standard category; } \\
& D e(k)=\sqrt{\sum_{i=1}^{n}\left(1-\frac{I(k)}{I(e)}\right)^{2} x p i} \begin{array}{l}
I i(k)-\text { the index of the direct or indirect performance criterion } \\
I i(e)-\text { the index of the performace criterion "i" of the } \\
\text { category of audited entities considered standard (with optimal }
\end{array} \\
& \text { value for that certain criterion); } \\
& p i \text { - the importance coefficient given to the performance } \\
& \text { criterion " } \mathrm{i} \text { ". }
\end{aligned}
$$

The final scores method, the 4th method of competitiveness analysis applied for the 4 categories of audited entities involves the value aggregation achieved through the first three methods in order to establish a final competitiveness ranking. This method is based on granting for each place from the competition a differentiate score and to add all these scores. The final classment will be determined according to the descending order of the scores, as it follows:

$$
P k=\sum_{j=1}^{m} P j(k) \quad \begin{aligned}
& \text { Where, } \\
& P(k)-\text { the total score cumulated by each of the } 4 \text { categories of } \\
& \text { audited entities; } \\
& P j(k)-\text { the score for each place " } \mathrm{j} \text { " of every category of audited } \\
& \text { entities "k". }
\end{aligned}
$$

Results and Discussion

After mathematically processing the data obtained for the 4 categories of audited entities (with or without foreign participation to the share capital, respectively with or without foreign 
management), starting from the first three above mentioned methods of competitiveness analysis, the following information has been obtained:

The competitiveness of the categories of audited entities

Table no. 2 based on the used analysis methods

\begin{tabular}{|c|c|c|c|c|c|c|c|c|c|c|c|c|}
\hline \multirow{4}{*}{$\begin{array}{c}\text { Category } \\
\text { of audited } \\
\text { entities }\end{array}$} & \multicolumn{12}{|c|}{ Method of competitiveness analysis } \\
\hline & \multicolumn{6}{|c|}{ Statistical version } & \multicolumn{6}{|c|}{ Economical version } \\
\hline & \multicolumn{2}{|c|}{$\begin{array}{l}\text { Synthetic } \\
\text { indicator }\end{array}$} & \multicolumn{2}{|c|}{$\begin{array}{c}\text { Comparison } \\
\text { matrix }\end{array}$} & \multicolumn{2}{|c|}{ Distance } & \multicolumn{2}{|c|}{$\begin{array}{l}\text { Synthetic } \\
\text { indicator }\end{array}$} & \multicolumn{2}{|c|}{$\begin{array}{c}\text { Comparison } \\
\text { matrix }\end{array}$} & \multicolumn{2}{|c|}{ Distance } \\
\hline & Amount & Top & Amount & Top & Amount & Top & Amount & Top & Amount & Top & Amount & Top \\
\hline$c_{\mathrm{s}}$ & 0.7 & 3 & 1.6 & 3 & 1.4 & 2 & -22.7 & 3 & 0.60 & 1 & 0.5 & 2 \\
\hline$c_{\text {. }}$ & 1.0 & 1 & 3.0 & 1 & 2.7 & 4 & -86.4 & 4 & 0.32 & 2 & 0.9 & 4 \\
\hline$c_{i}$ & 0.9 & 2 & 2.3 & 2 & 1.0 & 1 & -20.9 & 1 & 0.25 & 3 & 0.3 & 1 \\
\hline$c_{4}$ & 0.4 & 4 & 1.5 & 4 & 1.9 & 3 & -21.8 & 2 & 0.18 & 4 & 0.6 & 3 \\
\hline
\end{tabular}

Source: Statistical processing performed by the authors

he application of the 4th method (the final scores method) ensures a centralized situation concerning the competitiveness of the 4 categories of audited entities. By taking into consideration the scores cumulated by each category of audited entities according to their rank in the hierarchy and their cumulation by using the above mentioned method, we can obtain a final situation of the competitiveness for the period 2008-2011 of the entities audited between 2005-2012 according to the nature of participation to the share capital and to the type of management:

Table no. 3

The competitiveness of audited entities according to the structure of share capital and the type of management

\begin{tabular}{|c|c|c|c|c|c|c|c|c|c|}
\hline \multirow{2}{*}{ Rank } & \multirow{2}{*}{ Score } & \multicolumn{3}{|c|}{$\begin{array}{c}\text { Statistical } \\
\text { version }\end{array}$} & \multicolumn{2}{|r|}{$\begin{array}{c}\text { Economical } \\
\text { version }\end{array}$} & & \multicolumn{2}{|c|}{$\begin{array}{c}\text { Final } \\
\text { version }\end{array}$} \\
\hline & & $\begin{array}{l}\text { Synthetic } \\
\text { indicator }\end{array}$ & $\begin{array}{c}\text { Comparison } \\
\text { matrix }\end{array}$ & Distance & $\begin{array}{l}\text { Synthetic } \\
\text { indicator }\end{array}$ & $\begin{array}{c}\text { Comparison } \\
\text { matrix }\end{array}$ & Distance & Score & Rank \\
\hline I & 4 & $c_{5}$ & $c_{z}$ & $c_{z}$ & $c_{1}$ & $c_{1}$ & $c_{z}$ & $20 \mathrm{p}$ & $c_{3}$ \\
\hline II & 3 & $c_{7}$ & $c_{z}$ & $c_{1}$ & $c_{*}$ & $c_{7}$ & $c_{2}$ & $16 p$ & $c_{2}$ \\
\hline III & 2 & $c_{2}$ & $c_{2}$ & $\mathrm{C}_{4}$ & $c_{2}$ & $c_{z}$ & $c_{4}$ & $14 p$ & $c_{2}$ \\
\hline IV & 1 & $\mathrm{C}_{4}$ & $C_{4}$ & $C_{z}$ & $c_{z}$ & $\mathrm{c}_{4}$ & $c_{z}$ & $10 \mathrm{p}$ & $c_{*}$ \\
\hline
\end{tabular}

Source: Statistical processing performed by the authors

The most competitive category of audited entities are those with foreign participation to share capital and with local management $\left(C_{a}\right)$. The Romanian management is the most competitive in local environment. It seems that within the same category of audited entities: those with foreign participation to share capital are less competitive than those with foreign management $\left(\mathrm{C}_{1}\right)$. The less competitive category of audited entities is that which involves neither foreign participation, nor foreign management $\left(\mathrm{C}_{4}\right)$. Therefore, it seems that a feature of competitiveness is primarily the participation to share capital and only secondly the type of management. Therefore, the first hypothesis $\mathrm{H} 1$,Is there a condition between a certain structure of the share capital and of the management, on one side, and the audited entities' competitiveness, on the other side?" is confirmed. One can see that as the competitiveness for the 4 categories of audited entities increases, also the preference to require the Big 4 audit services evolves proportionally. So, the hypothesis $\mathrm{H} 2$ 
„Do the audited entities which are more competitive at national level manifest a tendency to request the audit services provided by entities from the Big 4 category?" can be considered as confirmed.

\section{The concordance between the competitiveness of audited entities and requiring the audit services}

\begin{tabular}{|c|c|c|}
\hline \multicolumn{2}{|l|}{ Classment of the competitiveness of audited entities } & Percentage of the entities audited \\
\hline Category of audited entities & $\underset{1}{S y m b}$ & $\begin{array}{c}\text { by companies from Big } 4 \text { category } \\
\qquad(\%)\end{array}$ \\
\hline $\begin{array}{l}\text { With foreign participation to share capital and without } \\
\text { foreign management }\end{array}$ & $c_{z}$ & 25 \\
\hline $\begin{array}{l}\text { With foreign participation to share capital and with } \\
\text { foreign management }\end{array}$ & $\mathrm{c}_{\mathrm{t}}$ & 23 \\
\hline $\begin{array}{l}\text { Without foreign participation to share capital and with } \\
\text { foreign management }\end{array}$ & $c_{\mathrm{n}}$ & 19 \\
\hline $\begin{array}{l}\text { Without foreign participation to share capital and without } \\
\text { foreign management }\end{array}$ & $c_{4}$ & 5 \\
\hline
\end{tabular}

Source: Statistical processing performed by the authors

If according to the previous specialized studies, at international level, the companies from the Big 4 category have a certain dominance regarding the audit services, this situation does not apply at national level, for Romania. According to the study's results, only an average of $18 \%$ of the audited entities require the audit services provided by the Big 4 . Even the maximum percentage of $25 \%$ achieved by the most competitive audited entities is quite low. Starting from these considerations, we find that the third hypothesis of the study $\mathrm{H} 3$,Is there a preference for Big 4 auditors also amongst Romanian audited entities?", is not confirmed.

\section{Conclusions}

The credibility and relevance of the study results in time and space are supported by several arguments. Firstly, we can mention the fact that, at country-level, a representative major Romanian region was selected in order for the study results to be extrapolated at Romanian level. If we approach the data obtained for the North-West region, from this perspective, they are exhaustive: all audited entities were included in the study. In order to confer an extra relevance in time, we took into consideration entities which benefited from audit services for a long period of time, repectivelly during 2005-2012. Also, taking into account the financial situations published by these entities audited between 2008-2011, is able to complete the credibility and relevance in time of the study's conclusions. The application of two large categories of methods of competitiveness analysis: statistical and economical, each one of them comprising 3 other types of methods which in the end are centralized, confers unity to the research conclusions. As for the audited entities, the main element influencing competitiveness is the existence of foreign invesments form of participation to share capital. Only secondly, the type of management is a key factor in this respect . There is a well outlined tendency (preponderance) of the competitive entities to require services provided by the Big 4, directly proportional with the development of competitiveness. The justification can be the same with the one mentioned by the specialized literature: the intention to confer more credibility to significant performances by achieving a confirmation from well known financial auditors concerning the fact that the financial situations are drawn in accordance with the law and the generally accepted accounting principles, under all significant aspects. If at international level, the entities from the Big 4 category hold the supremacy, not the same situation applies at national level, in Romania. According to this study, only $18 \%$ of the audited entities benefit from audit services provided by the Big 4, irrespective of their level of competitiveness, the 
structure of share capital or the structure of management. The explanations can be diverse, ranging from the possible higher costs of certain contracted audit services to the fact that the percentage of competitive entities that would opt for more credibility conferred by the auditors from the Big 4 category, within the total of audited entities al national level is very small.

No doubt, the up-scaling of the results of research faces inherent limits to any research that uses samples. Given the fact that stratified sampling was supported and justified, the inherent error of estimation cannot be of significance. It is much more relevant that the models used within this paper for measuring the competitiveness according to the structure of the managerial team (foreign and local management) and structure type of the share capital for the entities audited/or not by auditors from Big4, can be applied at international level, for a certain geographical area or for different sectors of activity.

\section{References}

1. Achim M.V., 2009. Analiza economico-financiară, Ed. Economică, Bucharest.

2. Basioudis I.G., Francis J.R. 2007. Big 4 Audit Fee Premiums for National and Office-Level Industry Leadership in the United Kingdom, Auditing: A Journal of Practice \& Theory 26 (2), 143-166.

3. Bedard J.C., Johnstone K.M., 2004. Earnings Manipulation Risk, Corporate Governance Risk and Auditor's Planning and Pricing Decisions, Accounting Review, 79, 277-304.

4. Boone J.P., Khurana I.K., Raman K.K. 2010. Do the Big 4 and the Second-tier firms provide audits of similar quality?, Journal of Accounting and Public Policy, 29, 330-352.

5. Boța-Avram C., 2012. Determining a scoring of financial audit practices used by most significant companies listed on Bucharest Stock Exchange in the context of corporate governance, Revista Audit Financiar, 10 (94), 30-40.

6. Boța-Avram C., Răchişan P.R., 2013. The influence of corporate governance on the strength of auditing and reporting standards: Evicende from EU countries, Revista Audit Financiar, 11(98), 16-22.

7. Butterworth S., Houghton K.A., 1995. Auditor Switching: The Pricing of Audit Services, Journal of Business Finance \& Accounting, 22, p. 323-344.

8. Cameran M., 2005. Audit fees and the large auditor premium in the Italian market, International Journal of Auditing, 9, 129-146.

9. Caneghem T., 2010. Audit pricing and the Big4 fee premium: evidence from Belgium, Managerial Auditing Journal, 25 (2), 122-139.

10. Carcello J.V., Hermanson D.R., Neal T.R., Riley R.A.Jr., 2002. Board Characteristics and Audit Fees, Contemporary Accounting Research, 19, 365-384.

11. Chan P., Ezzamel M., Gwilliam D., 1993. Determinants of Audit Fees for Quoted UK Companies, Journal of Business Finance and Accounting, 20, 765-786.

12. Chung D., Lindsay W., 1988. The Pricing of Audit Services: The Canadian Perspective, Contemporary Accounting Research, 5, 19-46.

13. Craswell A.T., Francis J.R., Taylor S.L., 1995. Auditor Brand Name Reputations and Industry Specializations, Journal of Accounting and Economics, 20, 297-322.

14. DeFond M.L., 1992. The Association Between Changes in Client Firm Agency Costs and Auditor Switching, Auditing: A Journal of Practice \& Theory, 11, 16-31.

15. DeFond M., Francis J.R., Wong T.J., 2000. Auditor Industry Specialisation and Market Segmentation: Evidence From Hong Kong, Auditing: A Journal of Practice and Theory, 19, 49-66.

16. Dickins D., Higgs J.L., 2005. Interpretation and use of Auditor Fee Disclosures, Financial Analysts Journal 61, 96-102. 
17. Dodd P., Dopuch N., Holthausen R.W., Leftwich R. 1984. Qualified Audit Opinions and Stock Prices: Information Content, Announcement Dates and Concurrent Disclosures, Journal of Accounting and Economics, 6 (1), 3-38.

18. Dopuch N., Holthausen R.W., Leftwich R., 1986. Abnormal Stock Returns Associated With Media Disclosures of 'Subject to' Qualified Audit Opinions, Journal of Accounting and Economics 8 (2), 93-117.

19. Firth M., 1978. Qualified Audit Reports: Their Impact on Investment Decisions, Accounting Review, 53, 642-650.

20. Ferguson A., Stokes D., 2002. Brand Name Audit Pricing, Industry Specialization and Leadership Premiums Post Big 8 And Big 6 Mergers, Contemporary Accounting Research 19, p. 77-110.

21. Francis J., 1984. The Effect of Audit Firm Size on Audit Prices, Journal of Accounting and Economics 6, p. 133-151.

22. Francis J.R., Maydew E.L., Sparks H.C. 1999. The role of Big 6 auditors in the credible reporting of accruals, Auditing: A Journal of Practice \& Theory, 18, 17-34.

23. Frankel R.M., Johnson M.F., Nelson K.K., 2002. The Relation Between Auditors' Fees for Nonaudit Services and Earnings Management, Accounting Review 77 (Suppl.), 71-105.

24. Gotti G., Han, S. Higgs J.L., Kang, T., 2012. Managerial Stock Ownership, Analyst Coverage and Audit Fee, Journal of Accounting, Auditing \& Finance, 27 (3), 412-437.

25. Gregory A., Collier P., 1996. Audit Fees And Auditor Change; An Investigation of The Persistence of Fee Reduction by Type of Change, Journal of Business Finance \& Accounting 23(1), 13-28.

26. Higgs J.L., Skantz T.S., 2006. Audit and Nonaudit Fees and the Market's Reaction to Earnings Announcements, Auditing: A Journal of Practice and Theory 25, p. 1-26.

27. Ireland J.C., Lennox, C.S., 2002. The Large Audit Firm Fee Premium: A Case of Selectivity Bias?, Journal of Accounting, Auditing and Finance 17 (1), 73-91.

28. Niskanen M., Karjalainen J., Niskanen J., 2010. The Role of Auditing in Small, Private Family Firms: Is It About Quality and Credibility?, Family Business Review 23 (3), p. 230245.

29. Palmrose Z., 1986. Audit Fees and Auditor Size: Further Evidence, Journal of Accounting Research, 24, 97-110.

30. Pong C.M., Whittington G., 1994. The determinants of audit fees: some empirical models, Journal of Business Finance and Accounting, 21, 1071-1095.

31. Răchişan P.R., Bonaci C.G., 2007. Mergers and acquisitions-significant case studies on the local market of Cluj-Napoca within the recent past, Annals of University of Oradea, Faculty of Economic Sciences, 16(3), 560 - 566.

32. Simon D.T., Francis J.R., 1988. The Effects of Auditor Change on Audit Fees: Tests of Price, Cutting and Price Recovery, Accounting Review, 63, 255-269.

33. Thornton D.B., Moore G., 1993. Auditor Choice and Audit Fee Determinants, Journal of Business Finance and Accounting, 20 (3), 333-349.

34. Topor D., Dorin I., Puțan A., 2011. The role of cost information in decision-making. Case study, Annales Universitatis Apulensis Series Oeconomica, 2(13), 315-324.

35. Weets V., Jegers M., 1997. Are the 'Big Six' 'big' in Belgium?”, European Accounting Review 6 (4), 773-789.

36. Whisenant S., Sankaraguruswamy S., Raghunandan K. 2003. Evidence on the Joint Determination of Audit and Non-audit Fees, Journal of Accounting Research, 41, p.721744. 